\title{
Imported Traditional Pottery: Methods of Overcoming the Challenges for Traditional Ceramics Industries in Oman
}

\author{
Badar Mohammed Almamari \\ Department of Art Education, Sultan Qaboos University, Muscat, Oman \\ Email address: \\ badaralmamari@hotmail.com \\ To cite this article: \\ Badar Mohammed Almamari. Imported Traditional Pottery: Methods of Overcoming the Challenges for Traditional Ceramics Industries in \\ Oman. Humanities and Social Sciences. Vol. 5, No. 1, 2017, pp. 1-4. doi: 10.11648/j.hss.20170501.11
}

Received: September 21, 2016; Accepted: December 6, 2016; Published: January 14, 2017

\begin{abstract}
In the new global economy, the development of traditional ceramics industries has become a central issue for individual ceramicists and craft enterprises alike. In Oman, over the past decade the Public Authority for Crafts Industries (PACI) has played a strong role in supporting the traditional ceramics industry. However, recently, competition from imported pottery and the negative impacts on local markets has become a pressing issue. The purpose of this paper is to address the ways in which individual Omani ceramicists and traditional pottery enterprises can successfully compete against imported ceramics.
\end{abstract}

Keywords: Pottery, Imported Goods, Design, Oman

\section{Introduction}

Nearly two-thirds of ceramic tableware in Oman now comes from abroad (PACI, 2016). Although extensive studies have been conducted into crafts consumption and marketing, very limited research has sufficiently explored competition from imported ceramics and its negative impact on local markets (Richardson and Dorr, 2003). Exploring the threat of imported pottery for local traditional craftspeople would seem to link clearly to the subject of protecting local ceramicists. Therefore, it is impossible to study this issue and contribute to this area of research without examining the challenges that the Omani craft industry is facing in general.

Today, modern factories are responsible for the distribution and sale of their goods, and small crafts enterprises, including pottery workshops, which are struggling to stay afloat in Oman, cannot afford to enter the international market and accept goods (crafts) from abroad.

This research investigated the issue of the marketing and consumption of traditional pottery in Oman. Specifically, it aimed to examine 'imported readymade traditional pottery to the country', which has caused real damage to the local traditional ceramics industry. The research used a qualitative methodology. Participants were asked direct structured questions in face-to-face interviews. Participants from the Marketing Unit at PACI (including salespeople in branches of the Omani Craftsman's House $(\mathrm{OCH})$ ) were the most significant sample in this research: on the one hand, they ensured the credibility and validity of the data; on the other, they ensured the availability of data from stored documents and software. Additionally, the ceramicists who participated provided valuable information, particularly where their voices countered the claims of official executives. Rather than using open-ended questions to start each interview, direct structured questions were asked. Direct structured questions were also asked when the researcher wanted to obtain statistical data from the participants.

In 1990 the United States of America issued the Indian Arts and Crafts Act (Public Law 101-644) to protect Native American crafts. Similarly, in general, Omani ceramicists and craftspeople expressed that they believe the government (PACI) is responsible for protecting them. Most of the ceramicists who participated in this research agreed that this topic comes under the categories of marketing and commerce and that the challenge will be overcome only if PACI takes more cultural and artistic actions.

Regarding the possible local cultural and artistic actions, the most interesting results arising from the collected data are as follows. Ceramicists who participated suggested that traditional Omani artistic designs and patterns should be documented and made accessible only to local potters. They also suggested that specific 
materials should be identified that can be used only by Omani potters and that different media should be used to communicate the importance of local ceramicists' tableware as an exceptional Omani handcraft. This group of ceramicists accepted that Omani decision-makers cannot stop commercial goods from entering the local Omani pottery market because of certain international trade agreements; however, they can create an internal framework to stop the imitation of themes used in traditional Omani pottery. For example, a participant from the Department of Marketing at the PACI head office who is considered as the official link between the head office and $\mathrm{OCH}$ salespeople said that it is impossible to prevent importers from bringing in commercial ceramic tableware from countries such as China and India, because there are international commercial agreements. He explained that the only thing PACI can do (and must do) is to pass laws that prevent the reproduction of traditional Omani pottery styles.

In contrast, among the above-mentioned sample of participants who believe that cultural and artistic reformations in Omani pottery are the only solution to the problem, a minority showed despondency and said they felt that this problem is out of control. They believe that PACI cannot face up to the negative impact of imported commercial pottery on local markets. It is worth mentioning that this sample of interviewees included some marketing salespeople from the Department of Marketing at PACI; this reveals that dissatisfaction has reached even the authority's marketing decision-makers.

Likewise, a substantial number of statistics published by PACI and other sources have been reviewed regarding this issue. For example, in the published report Results of the First Survey for Crafts Industries (2008), PACI stated that there are three methods of protecting Omani pottery and traditional ceramics from competition from imported pottery: quality, efficiency and proficiency (p.23). Consequently, there is a definite need to raise awareness of the negative impacts of imported commercial pottery on all stakeholders in the traditional ceramics and pottery sector, such as individuals and organizations making, selling, importing and exporting pottery and those supplying pottery materials.

\section{The Negative Impacts of Imported Pottery and Methods of Protecting Traditional Pottery Crafts}

As mentioned above, the contributions from ceramicists participating in this investigation fall into two main perspectives. The first perspective emphasizes that PACI should have the capacity to launch specific strategies to support local consumer culture, make regulations and take action to preserve local traditional ceramicists and support them to compete successfully with foreign (imported) ceramics and pottery. The participating ceramicists who had this point of view provided several suggestions in their interviews, which will be discussed in this section. The second perspective articulated by participating ceramicists seemed to be one of total despondency regarding any future treatments or official interventions to help them compete with imported reproductions of traditional Omani ceramics and pottery. Therefore, in this case, it is important to focus on the first perspective in order to make use of ceramicists' suggestions on the matter.

It is essential to ask why Omani ceramicists are worried about imported pottery. Two possible answers were expected. The first of these was that Omani ceramicists might not be as professional (skilled and trained) as ceramicists in other countries, so Omani ceramicists wish to avoid competing with professional non-Omani ceramicists. The second was that local ceramicists may be required to stop importing pottery from abroad for cultural purposes, where imported pottery has a negative impact on the Omani pottery industry and its inherited identity.

No matter what the answers to the question above, focusing on taking advantage of the regional and cultural characteristics of traditional Omani pottery is considered to be the definitive requirement for overcoming the challenges caused by imported goods. Local cultural values may be the only attributes that can make Omani pottery distinct from imported goods. In other words, the representation of local people's intangible cultural heritage in traditional ceramics and pottery could make an exceptional contribution to distinguishing local pottery from duplicated imported goods. It has been asserted that 'culture and contemporary craft (including pottery) plays an important role in selfactualisation and the expression of who we are and what we want to be' (Brigid Howarth Consultancy, 2009, p.4). In other words, the exchange of pottery between maker (ceramicist) and receiver (customer) means the exchange of cultural and heritage values, where the consumer receives a 'tangible object' attached to 'intangible cultural values'. Without intangible cultural values, the tangible object is worth only its functional purpose. Material culture (tangible heritage), has repeatedly been considered by societies as a medium that conveys their cultural 'footprint' and represents their cultural heritage (intangible cultural values), which is expressed to consumers in the form of craft objects (Keitumetse and Nthoi, 2009). In the case of Omani pottery, it is crucial to recognize the intangible values of pottery-making. Although PACI has strong connections with the United Nations Educational, Scientific and Cultural Organization (UNESCO), insufficient effort is being made to focus on the values of traditional Omani craftsmanship, including ceramics and pottery. This disconnect between traditional craftsmanship and intangible cultural heritage could lead to less recognition of the importance of intangible cultural heritage in Omani pottery when developing local goods to compete with imported goods.

One of the sub-questions of this study was how much effort PACI is making to collect data on the consumption of 
pottery and traditional ceramics in Omani society. The interviewees asserted that progress has been made in this aspect of data collection. However, data collection was one of the most commonly recognized weaknesses of the authority in relation to the issue of pottery consumption. Let us consider that the authority carries out surveys to collect consumers' opinions in order to measure the demand for traditional pottery and ceramics within Oman. The results will act as guidelines for Omani ceramicists, but not for foreign ceramicists. Therefore, local ceramicists will be able to control their production to meet local demand, which will reduce competition from imported pottery. From this perspective, the solution comes from inside, not outside, as suggested by the interviewees and PACI decision-makers, according to the collected data.

In addition to the significance of intangible cultural heritage in competing with imported pottery, as discussed above, it is worth discussing participants' suggested actions to overcome this challenge. The research participants expressed several arguments regarding the challenge of imported pottery. They suggested, directly and indirectly, some practical actions that could be taken to overcome the negative impacts of cheap imported pottery on the local Omani pottery industry.

The first argument to be discussed is the possibility of passing laws to prevent non-Omani ceramicists from being involved in the pottery industry, either as individual ceramicists or owners of pottery enterprises. The second argument is that the authority must concentrate on making types of pottery that are more expensive when they are imported, because of transportation or other risks associated with importation. The third argument is that ceramicists and pottery enterprises must focus on making pottery that is of a high quality, spending longer on production (for example, one piece per month) rather than making many low-quality products each day. Finally, interviewees suggested using intellectual property laws to protect certain unique traditional Omani pottery styles. This method is already being applied within PACI.

The first point - preventing non-Omanis from being involved in the pottery industry - led to an investigation of the position of 'Omanization' in the pottery industry in general and in PACI pottery centres in particular. The Omanization policy is a plan that was established by the Omani government in 1998 in order to guarantee a career for every Omani citizen and decrease the country's dependence on foreign workers (Ministry of Information, Sultanate of Oman, 2011). In fact, PACI has achieved good results in the Omanization project: in 2008 (the only statistic available on this issue) Omanis workforce formed $99 \%$ compared with only $1 \%$ of foreigners in the main administration office in Muscat (PACI, 2008, p.14). Although the data published by PACI did not show the distribution of ceramicists (Omanis/non-Omanis) in pottery centres, the researcher noted that all ceramicists in all visited centres were Omanis. If this is the case, where is the problem?
Some participants asserted that the problem lies in (a) private pottery centres (such as the Handicrafts Centre in Muscat, which specializes in making pottery) where all the ceramicists come from Asian countries; and (b) hidden nonOmani ceramicists who work in non-registered enterprises. Although PACI has a dedicated inspection team to control these illegal activities, it is recognized that this team cannot stop these actions altogether, because non-Omani ceramicists continue to be available on the market. The solution could be to inspect the market, rather than the places where the goods are made (hidden workshops), which are less recognizable in the country. In Mattrah (the Dark Market) in the heart of the capital, Muscat, it is easy to observe that a lot of pottery on sale has been made in Oman but not by Omani hands. This situation also exists in Nizwa, Finja and Salalah (pottery coal burners).

PACI must also focus on making ceramics that are considered more expensive when imported from abroad. For example, in the field of pottery crafts, the pottery centre of Bahla makes a special type of pot that costs more when it is imported. The size, durability and glaze type (anti-scratch) of the pots should be accounted for in order to compete with imported pots. The traditional design of large storage pots, khars (a storage jar that is usually at least $100 \mathrm{~cm}$ high), is still in demand today. However, at the same time, large imported pots are available on the market. Importers have continued to buy in this type of pot because local producers were not making enough of them. As this is a large type of pot, it takes up a lot of space in importing containers. In addition, because of the pot's oval (egg-shaped) design, it is difficult to store pieces inside each other, unlike other types of pottery (plates, cups and soup bowls).

PACI must also concentrate on making thin pottery, rather than thick pots. Thin pottery is especially in demand in terms of tableware. Because this type of pottery is usually fragile and some pieces are often broken during transportation (causing the importer to raise the price to guarantee profits), it is worth concentrating on making thin pottery locally in order to take advantage of exporters' risks.

Pottery glazes (decoration) can also give local pottery an advantage over imported pots. Developing different glazing techniques can help Omani pottery compete with imported ceramics (especially colourful Asian products). According to the findings of this research, ceramicists at the state pottery centre of Bahla and the Handicrafts Centre in Muscat have never used certain glazing techniques, such as soda glazing, crystalline glazing, raku firing and ash glazing. Because there is market demand for all the glazing techniques mentioned above, the market relies on importing pottery. To summarize this point, the daily work of each craftsman in PACI centres must be organized carefully to meet ceramicists' needs by planning their time, tasks (quantity and quality) and income. This may be the only way in which to protect craftspeople from competition from foreign producers. Figure 1 summarizes the strategies explained above. 


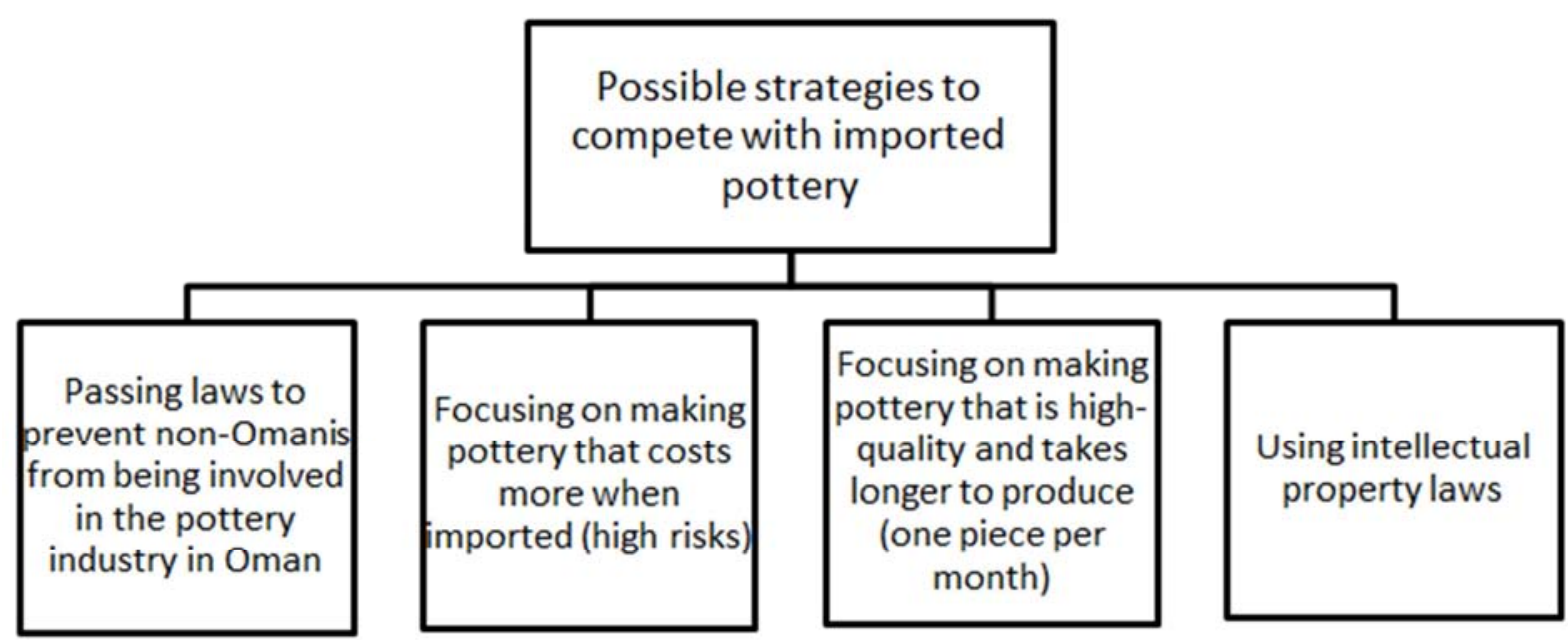

Figure 1. Possible strategies to compete with imported pottery.

\section{Conclusion}

In conclusion, the strategies suggested in this paper propose to reduce the harmful consequences of imported pottery on the Omani pottery market. As mentioned in the literature and confirmed by interviewees in this research, it is not possible to stop other nations exporting their goods to Oman. Therefore, these suggestions should be considered as a minimum intervention in order to overcome this challenge.

\section{Acknowledgment}

This research was supported by Sultan Qaboos University (Internal Research Fund). I would like to thank my colleagues from SQU and especially the administrative staff from college of Education.

\section{References}

[1] Keitumetse, S. O. \& O. Nthoi. 2009. Investigating the Impact of World Heritage Site Tourism on the Intangible Heritage of a Community: Tsodilo Hills World Heritage Site, Botswana. International Journal of Intangible Heritage 4: 144-149.
[2] Reporters, (2009) The Indian Arts and Crafts Act of 1990. US Department of the Interior, Indian Arts and Crafts Board. Retrieved 5 Dec 2016.

[3] Reporters, (2009) Stimulating demand: market development strategy for contemporary crafts in the North East. Brigid Howarth Consultancy Ltd. 1 (1), 1-69.

[4] Richardson N, Dorr M. 2003. The Craft Heritage of Oman, Dubai, Motivate Publication.

[5] PACI (2008). Results of Crafts Industries First Field Survey. Muscat: Public authority for Crafts Industries. 68.

[6] PACI (2016). Statistical Year Book 2016. Muscat: Public authority for Crafts Industries. 1-38.

[7] PACI (2007). Statistical Year Book 2007. Muscat: Public authority for Crafts Industries. 1-40.

[8] PACI (2008). Statistical Year Book 2008. Muscat: Public authority for Crafts Industries. 1-35.

[9] PACI (2009). Statistical Year Book 2009. Muscat: Public authority for Crafts Industries. 1-37.

[10] PACI (2010). Statistical Year Book 2010. Muscat: Public authority for Crafts Industries. 1-35. 